\title{
Plasma and ovarian oestradiol and the variability in the LH surge induced in ewes by the ram effect
}

\author{
Claude Fabre-Nys ${ }^{1}$, Audrey Chanvallon ${ }^{1,+}$, Nathalie Debus ${ }^{2}$, Dominique François $^{3}$, \\ Frédéric Bouvier ${ }^{4}$, Joelle Dupont ${ }^{1}$, Lionel Lardic ${ }^{1}$, Didier Lomet ${ }^{1}$, Christelle Ramé ${ }^{1}$ \\ and Rex J Scaramuzzi ${ }^{1,5}$
}

${ }^{1}$ UMR 7247 Physiologie de la Reproduction et des Comportements, CNRS, Institut Français du Cheval et de I'Équitation, Université de Tours, PRC Centre INRA Val de Loire, 37380 Nouzilly, France, ${ }^{2}$ UMR 868 'Elevage des Ruminants en Régions Chaudes', 2 Place Viala, 34060 Montpellier Cedex 1, France, '3INRA SAGA, Chemin de Borde-Rouge Auzeville, BP 52627, 31326 Castanet Tolosan, France, ${ }^{4}$ INRA Bourges, Domaine de la Sapinière, 18390 Osmoy, France and ${ }^{5}$ Department of Comparative Biological Sciences, Royal Veterinary College, Hawkshead Lane, South Mimms, Hertfordshire AL9 7TA, UK

Correspondence should be addressed to C Fabre-Nys; Email: claude.fabre@tours.inra.fr

${ }^{+}$A Chanvallon is now at Institut de l'Élevage, Oniris, BP 40706, 44307 Nantes, France

\begin{abstract}
The proportion of anoestrous ewes ovulating after exposure to a sexually active ram is variable mainly due to whether an LH surge is induced. The aim of this study was to determine the role of oestradiol $\left(E_{2}\right)$ in the ram-induced LH surge. In one study, we measured the plasma concentrations of $E_{2}$ in ewes of different breeds before and after the 'ram effect' and related these patterns to the presence and latency of the LH surge, while another compared ovarian responses with the 'ram effect' following exposure to rams for 2 or $12 \mathrm{~h}$. In all ewes, the concentration of $E_{2}$ increased 2-4 $\mathrm{h}$ after rams were introduced and remained elevated for $14.5 \pm 0.86 \mathrm{~h}$. The quantity of $E_{2}$ secreted before the LH surge varied among breeds as did the mean concentration of $E_{2}$. The granulosa cells of IF ewes collected after $12 \mathrm{~h}$ exposure to rams secreted more E2 and progesterone and had higher levels of StAR than the $\mathbf{2} \mathrm{h}$ group but in MV ewes there was no differences between these groups for any of these parameters. These results demonstrate that the LH surge induced by the rams is a result of increased $E_{2}$ secretion associated with increased levels of STAR in granulosa cells and that these responses varied among breeds. The results suggest that the variable occurrence of a $\mathrm{LH}$ surge and ovulation may be the result of variable ovarian responses to the 'ram effect' and insensitivity of the hypothalamus to the $E_{2}$-positive feedback signal.

Free French abstract: A French translation of this abstract is freely available at http://www.reproduction-online.org/content/149/5/511/ suppl/DC1.
\end{abstract}

Reproduction (2015) 149 511-521

\section{Introduction}

In sheep, goats and many wild ungulates, reproduction is seasonal and the females give birth when the environmental conditions are most favourable for the survival of their young. Ewes have oestrous cycles when day length is decreasing (the breeding season), which stop as day length increases (anoestrus). During anoestrus, their ovaries release very little oestradiol $\left(E_{2}\right)$, there are no spontaneous pre-ovulatory luteinising hormone (LH) surges and the ewes do not ovulate. However, the introduction of a sexually active male into a group of seasonally anoestrous ewes will induce an immediate increase in the pulsatile secretion of $\mathrm{LH}$ (short-term $\mathrm{LH}$ response). This socio-sexual stimulation of ovulation often referred to as the 'ram effect', initiates a sequence of physiological events that in some of ewes culminates in a LH surge and ovulation (Martin et al. 1986, Ungerfeld 2007). A similar phenomenon occurs in goats and in many wild ungulates in which shortening and concentrating the period of sexual activity reduce the risks of predation. In farm animals, this is a simple technique for inducing fertile mating outside of the breeding season in a way that is compatible with sustainable, green and ethical agriculture (Martin et al. 2004). However, the response to the 'ram effect' is variable both among breeds and within breeds and this variability is a serious practical limitation to the more wide-spread use of this technique. The origins of this variability are poorly understood. In a previous study, we reported that $93 \%$ of ewes had 'short-term' $\mathrm{LH}$ responses to the 'ram effect'. We also reported that the 
frequency of subsequent $\mathrm{LH}$ surges was highly variable ranging from 0 to $100 \%$, depending on breeds and period of stimulation (Oldham et al. 1978, Chanvallon et al. 2011). Together, these results pointed to the induction of the LH surge as the major cause of variability of response to the 'ram effect'.

In all mammalian species, the LH surge is induced by an increase in secretion of the hypothalamic neuropeptide, gonadotrophin-releasing hormone $(\mathrm{GNRH})$. In species that ovulate spontaneously, such as the sheep, the rat, the rhesus monkey or the human, secretion of GNRH is tightly controlled by ovarian steroids: progesterone secreted by corpora lutea and $E_{2}$ secreted predominately by large oestrogenic follicles. The secretion of $E_{2}$ increases during the follicular phase and this increase is essential for the $\mathrm{LH}$ surge (positive feedback). The LH surge occurs only after a period of prolonged exposure to the above threshold concentrations of $\mathrm{E}_{2}$ (Corker et al. 1969, Karsch et al. 1973, 1979, Smith et al. 1975, Hauger et al. 1977). In sheep, the characteristics of the relationship between the preovulatory rise in systemic concentrations of $E_{2}$ and the onset of the LH surge, and presumably of GNRH, varies among breeds (Land et al. 1976, Cahill et al. 1981, Ben Saïd et al. 2007).

It is widely assumed that the LH surge occurring in anoestrous ewes after introduction of rams is induced by mechanisms similar to those occuring during the breeding season, that is, the increased pulsatile secretion of $\mathrm{LH}$ induced by exposure to rams increases the secretion of ovarian $\mathrm{E}_{2}$ that by positive feedback induces the preovulatory surges of GNRH and LH (Martin et al. 1986). However, there is very little published data describing the precise pattern of $E_{2}$ concentrations either before or after the 'ram effect'. In fact, one study from 1978 concluded that there was no change in the concentrations of plasma $E_{2}$ in ewes stimulated by the 'ram effect' (Knight et al. 1978). Recent results from our laboratory have indicated that there was a close relationship between the induction of a $\mathrm{LH}$ surge after introduction of rams and increased systemic concentrations of $\mathrm{E}_{2}$ at the time of the $\mathrm{LH}$ surge (Johnson et al. 2011).

Our hypothesis is that the plasma concentration of $E_{2}$ in anoestrous ewes can predict the likelihood and timing of the LH surge following the 'ram effect'. More specifically, we propose that among breed, variability in the $\mathrm{LH}$ response to the 'ram effect' is due to variability in the threshold concentration of $E_{2}$ necessary to trigger a LH surge (i.e. hypothalamo-hypophyseal sensitivity) and/or a failure of the ovaries to respond to the male-induced pulsatile secretion of $\mathrm{LH}$ thus, producing insufficient $\mathrm{E}_{2}$ to induce a $\mathrm{LH}$ surge (ovarian sensitivity). To test these hypotheses, we carried out two experiments. In the first, we measured the systemic concentrations of $E_{2}$ before and after the introduction of rams in four breeds of anoestrous sheep that have different patterns of response to the 'ram effect' and then related these concentrations to the occurrence and timing of the LH surge. In a second experiment, we compared the ovarian follicular response under conditions known to differentially affect LH secretion and ovulatory response to the 'ram effect' in two of the breeds studied in the first experiment.

\section{Materials and methods}

The experiments were carried out in accordance with French and European regulations on the care and welfare of animals in research and with authorisation of the Ministry of Agriculture and with their ethical approval (no. 006259 and 2012-01-2).

For our first study (the four breeds study), the plasma samples to be analysed were selected from an existing set of samples that had been previously collected for another experiment. The data from this earlier experiment have been published (Chanvallon et al. 2011). In this experiment, adults anoestrous ewes from four breeds (Mouton Vendéen (MV), Ile de France (IF), Romane (R) and $M d^{\prime}$ Arles (M)) were exposed to sexually active males at different periods of anoestrus and their responses recorded and analysed. In the published experiment, we reported the concentrations of $\mathrm{LH}$ from $-1.5 \mathrm{~h}$ before to $56 \mathrm{~h}$ after the 'ram effect' (samples every $15 \mathrm{~min}$ up to $+4 \mathrm{~h}$ and then every 4 to $+56 \mathrm{~h}$ ) and these data were used as the basis for the selection of ewes for the present experiment. We selected samples from ewes that had $\mathrm{LH}$ surges $2-56 \mathrm{~h}$ after ram introduction (IF, $n=18 ; \mathrm{M}, n=17 ; \mathrm{R}, n=15$ and $\mathrm{MV}, n=7$ ) as well as ten ewes that had not had a LH surge by $56 \mathrm{~h}$ (three ewes from IF, R and MV; one M). To avoid bias, we controlled for the possible effects of time of anoestrus by randomisation within anoestrous periods. $\mathrm{E}_{2}$ concentration was assayed in samples taken $1.5 \mathrm{~h}$ before and a few minutes before the introduction of the rams $(0 \mathrm{~h})$ and in those taken at 2, 4, 8 and $12 \mathrm{~h}$ after the introduction of the rams and then every $4 \mathrm{~h}$ until the LH surge or $56 \mathrm{~h}$ in ewes without a LH surge. Details of the blood sampling and processing procedures have been published (Chanvallon et al. 2011).

Anoestrous ewes from MV and IF breeds, known to differ in the occurrence of ovulation after exposure to rams (Chanvallon et al. 2011), were used in the second study (the ovarian response study). The ewes had been isolated from all contact with rams for more than 2 months before the start of the experiment. The treatments were i) exposure to sexually active rams for $2 \mathrm{~h}$ (male $2 \mathrm{~h}$ : IF, $n=6$ and $M \mathrm{~V}, n=4$ ), a condition that stimulates LH pulsatile secretion; ii) exposure to a sexually active ram for $12 \mathrm{~h}$ (male $12 \mathrm{~h}$ : IF, $n=9$ and $\mathrm{MV}, n=4$ ), a condition that induces a LH surge in some but not all ewes and iii) exposure to unfamiliar anoestrous ewes for $2 \mathrm{~h}$ (controls: IF, $n=6$ and $\mathrm{MV}, n=4$ ), a condition that has no effect on $\mathrm{LH}$ secretion. The ovaries of each ewe were collected at slaughter after $2 \mathrm{~h}$ ('control $2 \mathrm{~h}$ ' and 'male $2 \mathrm{~h}$ ' ewes) or $12 \mathrm{~h}$ ('male $12 \mathrm{~h}$ ' ewes) by a licensed butcher in the licensed abattoir at the INRA laboratory.

\section{Isolation and culture of granulosa cells}

Immediately after slaughter, the ovaries were removed and immersed for $15 \mathrm{~min}$ in isotonic saline containing Fungizone (Gibco BRL) and antibiotics (penicillin and streptomycin). 
For each ewe, granulosa cells from the right ovary were collected from different follicles as described below and stored at $-80^{\circ} \mathrm{C}$ before total RNA extraction. Those obtained from the left ovary were cultured. More precisely, the ovaries were transferred to culture plates containing McCoy's medium and the small follicle (SF; $1.0-2.0 \mathrm{~mm}$ ) medium follicle (MF; > 2.0-3.5 mm) and antral follicle (LF; > $3.5 \mathrm{~mm}$ ) were dissected free. Each follicle was then slit open in McCoy's medium, and granulosa cells were removed by gently scraping the interior surface of the follicle with a platinum loop. The cell suspensions were centrifuged at $300 \mathrm{~g}$ for $7 \mathrm{~min}$. The granulosa cells were pooled by follicle class within ovaries. Given the low number of granulosa cells for the MF and LF groups, only granulosa cells from the SF class were analysed for both $E_{2}$ and progesterone production and mRNA expression.

For the culture experiments, pellets were re-suspended in culture medium (McCoy's 5A medium (Sigma) containing bicarbonate supplemented with $20 \mathrm{mmol} / \mathrm{I} \mathrm{HEPES,} 100 \mathrm{kIU} / \mathrm{l}$ penicillin, $0.1 \mathrm{~g} / \mathrm{l}$ streptomycin, $3 \mathrm{mmol} / \mathrm{I}$ L-glutamine, $0.1 \%$ BSA (w/v), $0.1 \mu \mathrm{mol} / /$ androstenedione, $5 \mathrm{mg} / \mathrm{l}$ transferrin and $20 \mu \mathrm{g} / \mathrm{l}$ selenium). The granulosa cells were then cultured in serum-free conditions. Briefly, cells were counted and their viability was determined (ranged between 70 and $85 \%$ ) by Trypan blue exclusion. The cultures were performed in 48-well plates for the production of progesterone and $E_{2}$ or in six-well plates for the RNA measurements. The cells were cultured at $37^{\circ} \mathrm{C}$ in a humidified atmosphere with $5 \% \mathrm{CO}_{2}$ in a serumfree culture medium containing either no exogenous factors, ovine follicle-stimulating hormone $(\mathrm{oFSH})$ alone $\left(10^{-8} \mathrm{M}\right)$, insulin-like growth factor 1 (IGF1) alone $\left(10^{-8} \mathrm{M}\right)$ or their combination (oFSH+IGF1, $10^{-8} \mathrm{M}$ ) for $48 \mathrm{~h}$. For each ewe, each combination of treatment was tested in quadruplicate. After $48 \mathrm{~h}$ of stimulation, the collected medium was stored at $-20{ }^{\circ} \mathrm{C}$ before progesterone and $\mathrm{E}_{2}$ assay.

\section{RNA analysis}

Total RNA was extracted from SF granulosa cells obtained from right ovary of each group of ewe (exposure for 2-h to an unfamiliar ewe (control) or to a sexually active ram for either 2 or $12 \mathrm{~h}$ ) using RNeasy kits according to the manufacturer's procedure (Qiagen). The levels of RNA for STAR protein (STAR), $3 \beta$-hydroxy steroid dehydrogenase $(H S D 3 B)$ and P450 side chain cleavage enzyme (CYP11A1) was quantified by measuring the absorbance at $260 \mathrm{~nm}$. The samples were stored at $-80{ }^{\circ} \mathrm{C}$ until use. Reverse transcribed total RNA $(1 \mu \mathrm{g})$ was denatured and retro-transcribed with the reverse transcriptase Moloney murine leukaemia virus (MMLV; $15 \mathrm{U}$ ) in a $20 \mu \mathrm{l}$ reaction mixture containing $50 \mathrm{mM}$ Tris- $\mathrm{HCl}(\mathrm{pH} 8.3), 75 \mathrm{mM}$ $\mathrm{KCl}, 3 \mathrm{mM} \mathrm{MgCl} 2,200 \mu \mathrm{M}$ of each dNTP (Amersham),
50 pmol of oligo(dT)15 and $5 \mathrm{U}$ of ribonuclease inhibitor. All were incubated at $37^{\circ} \mathrm{C}$ for $1 \mathrm{~h}$. Targeted cDNAs were quantified by real-time PCR using SYBR Green Supermix (BioRad) and $250 \mathrm{~nm}$ of specific primers as given in Table 1, in a total volume of $20 \mu \mathrm{l}$ using a MyiQ Cycle device (Bio-Rad). The samples were tested in duplicate on the same plate and PCR amplification with water, instead of CDNA, was used systematically as a negative control. After incubation for $2 \mathrm{~min}$ at $50{ }^{\circ} \mathrm{C}$ and a denaturation step of $10 \mathrm{~min}$ at $95^{\circ} \mathrm{C}$, samples were subjected to 40 cycles $\left(30 \mathrm{~s}\right.$ at $95^{\circ} \mathrm{C}, 30 \mathrm{~s}$ at $60{ }^{\circ} \mathrm{C}$ and $30 \mathrm{~s}$ at $\left.72{ }^{\circ} \mathrm{C}\right)$, followed by acquisition of the melting curve. Primers' efficiencies $(E)$ were performed from serial dilutions of a pool of all cDNA analysed and ranged from 1.8 to 2 . Three reference genes: PPIA, RPL19 and ACTB were used (the description of these primers is given in Table 1). For each gene, expression was calculated according to primer efficiency and Cq: expression $=E^{-C q}$. Then, the relative expression of STAR, CYPAAA1 or $H S D 3 B /$ geometric mean of the three reference genes was analysed.

\section{Assay of LH in plasma}

The concentration of $\mathrm{LH}$ in plasma was measured by EIA as described previously (Faure et al. 2005). The sensitivity of the assay was $0.10 \mathrm{ng} / \mathrm{ml}$ and the intra-assay and inter-assay coefficients of variation (CV) for a reference sample $(0.5 \mathrm{ng} / \mathrm{ml})$ were 9.3 and $5.2 \%$ respectively.

\section{Assay of progesterone and $E_{2}$ in culture medium}

The concentration of progesterone in the culture medium was measured by an EIA protocol as described previously (Canepa et al. 2008). The intra-assay CV averaged $<10 \%$. The results are expressed as the amount of steroid (ng) secreted per $48 \mathrm{~h}$ per $100 \mathrm{mg}$ of protein. The results are expressed as mean \pm S.E.M. For each ewe, each combination of treatment was tested in quadruplicate. The $E_{2}$ concentration in the culture medium was determined by using by EIA using the $E_{2}$ Assay Kit from Cayman Chemical (distributed by Interchim, Montluçon, France). The intra-assay CV averaged $<10 \%$. The results are expressed as mean \pm s.E.M. For each ewe, each combination of treatment was tested in quadruplicate.

\section{Assay of $E_{2}$ in plasma}

The concentrations of $E_{2}$ in jugular venous plasma were determined using the HRP-E $\mathrm{E}_{2}$ DIASource Immunoassay ELISA Kit (E2-EASIA/KAP0621; DIASource immunoassay SA, Louvain la Neuve, Belgium), adapted for the detection of $E_{2}$ in ovine

Table 1 Oligonucleotide primers sequences.

\begin{tabular}{|c|c|c|c|}
\hline Gene & Protein & Forward $\left(5^{\prime}-3^{\prime}\right)$ & Reverse $\left(5^{\prime}-3^{\prime}\right)$ \\
\hline PPIA & Cyclophilin A & GCATACAGGTCCTGGCATCT & TGTCCACAGTCAGCAATGGT \\
\hline RPL19 & Ribosomal protein L19 & AATCGCCAATGCCAACTC & СССТTTCGСТTAССТАTACC \\
\hline$A C T B$ & Beta actin & ACGGAACCACAGTTTATCATC & GTCCСAGTCTTCAACTATACC \\
\hline CYP11AL & P450 side-chain cleavage enzyme & AGAGAATCCACTTTCGCCACATC & GGTCTTTCTTCCAGGTTCCTGAC \\
\hline$H S D 3 B 1$ & $3 \beta$-hydroxy steroid dehydrogenase & GTGAGCTTCСTGCTCAGTCC & СTCСTTGGTTTTCTGCTTGG \\
\hline STAR & STAR protein & CCCATGGAGAGGCTTTATGA & CCCATGGAGAGGCTTTATGA \\
\hline
\end{tabular}


plasma. Aliquots $(300 \mu \mathrm{l})$ of plasma, or standards in steroid-free plasma, in glass tubes were extracted with $3 \mathrm{ml}$ of ethyl acetate/cyclohexane (Carlo Erba RPE, 99.8\% min, for analysisACS reagent V/V) by mixing for $5 \mathrm{~min}$. After resting for $2 \mathrm{~h}$, tubes were centrifuged for $15 \mathrm{~min}$ and then frozen in liquid nitrogen. The solvent layer was decanted, transferred into new glass tubes and evaporated to dryness under nitrogen. The standards and samples were reconstituted in $160 \mu \mathrm{l}$ of $0.1 \mathrm{M}$ Tris (a mixture of Trisma base and Trisma hydrochloride, Sigma), $1 \mathrm{mM}$ EDTA (Titriplex III, Merck) and $150 \mu \mathrm{l}$ was incubated in an ELISA plate, previously coated with anti-rabbit mouse IgG from the DIASource Kit, with the antibody to $E_{2}$ also from the DIASource Kit but, diluted at $50 \%$ of the concentration recommended, for $24 \mathrm{~h}$ at $22{ }^{\circ} \mathrm{C}$ on a horizontal shaker set at $700 \pm 100$ revolutions $/ \mathrm{min}$. The HRP coupled $\mathrm{E}_{2}$ $\left(E_{2}-H R P\right)$ from the DIASource Kit $(50 \mu \mathrm{l})$ was added to each well at the concentration recommended for the kit, shaken for $1 \mathrm{~h}$ at $22{ }^{\circ} \mathrm{C}$ on a horizontal shaker set at $700 \pm 100$ revolutions/min and then for $23 \mathrm{~h}$ at $4{ }^{\circ} \mathrm{C}$ without shaking. The plate was washed three times with the washing solution supplied with the kit and dried on absorbent paper. Then, $200 \mu \mathrm{l}$ of $3,3^{\prime}, 5,5^{\prime}$ tetramethylbenzidine substrate were added to each well and incubated for $30 \mathrm{~min}$ at $22{ }^{\circ} \mathrm{C}$ on a horizontal shaker set at $700 \pm 100$ revolutions/min. Finally, $50 \mu$ of the STOP reagent also part of the kit $(0.9 \mathrm{~N}$ solution of sulphuric acid) was dispensed into each well. The absorbance of each well was read at a wavelength of $450 \mathrm{~nm}$ (with a reference wavelength at $620 \mathrm{~nm}$ ) within $1 \mathrm{~h}$ of the addition of the STOP reagent. The concentrations of $E_{2}$ were calculated using the RIA SMART programme (Canberra Packard-Packard instrument Co., SaintQuentin-en-Yvelines, France) with 4PL logistic regression.

\section{Validation of $E_{2}$ assay}

Cross-reactivities were $<2 \%$ for oestrone, oestriol, $E_{2}-3$ glucuronide and $E_{2}$-17-glucuronide, and $<0.1 \%$ for $E_{2^{-}}$ 17-valerate, cortisol, progesterone, DHEA-S, testosterone, androstenediol, norgestrel, premarin and equilin. The assay sensitivity was $0.39 \mathrm{pg} / \mathrm{ml}$. The recovery of $\mathrm{E}_{2}$ was tested by adding $0.5,1.0,2.0$ and $5.0 \mathrm{pg} / \mathrm{ml}$ of $\mathrm{E}_{2}$ to steroid-free plasma. The percentage recoveries of added $\mathrm{E}_{2}$ were 80, 109, 123 and $99 \%$ for $0.5,1,2$ and $5 \mathrm{pg} / \mathrm{ml}$ respectively. The fitted regression line had a slope of 1.03 and the correlation between added and recovered $E_{2}$ was 0.98 . The recovery of $E_{2}$ was similarly tested using demineralised water instead of steroid-free plasma. The percentage recoveries were respectively, 106, 83, 80 and $74 \%$ at $0.5,1.0,2.0$ and $5.0 \mathrm{pg} / \mathrm{ml}$, and the regression line has a slope of 0.73 and the correlation was 0.99 . The 'intra-assay' and 'inter assay' CV determined at three concentrations of $\mathrm{E}_{2}$ were as follows: 16.6 and $15.3 \%$ (at $0.46 \mathrm{pg} / \mathrm{ml}$ ), 11.9 and $11.7 \%$ (at $0.80 \mathrm{pg} / \mathrm{ml}$ ), 4.6 and $4.7 \%$ (at $5.13 \mathrm{pg} / \mathrm{ml}$ ).

\section{Statistical analyses}

$E_{2}$ data from the first study were analysed after grouping the data around time ' 0 ' relative to the introduction of rams. The pattern of $E_{2}$ concentrations was considered as 'discontinuous' if the concentrations of $E_{2}$ fluctuated more than $25 \%$ between
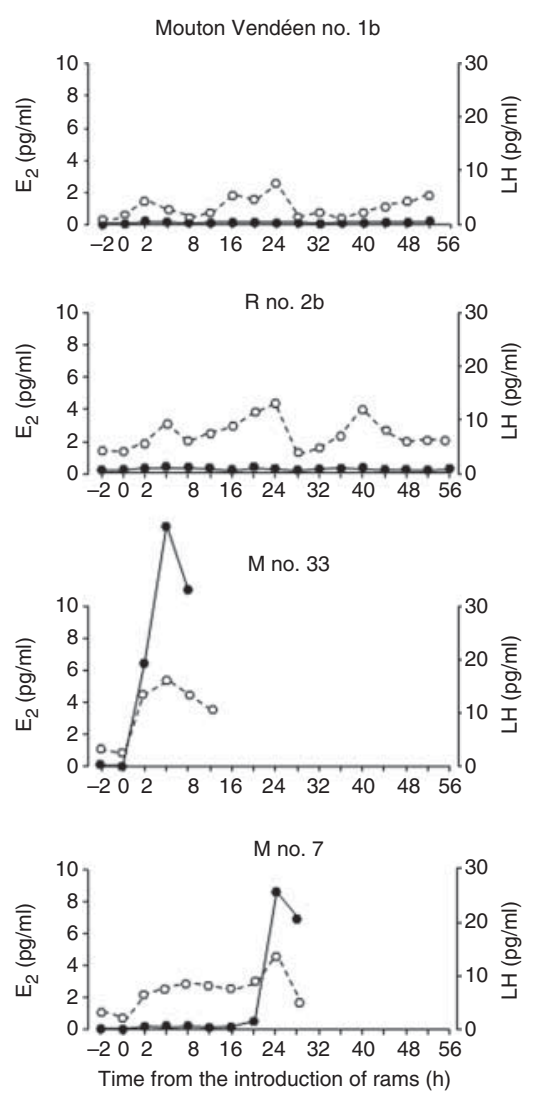

Reproduction (2015) 149 511-521
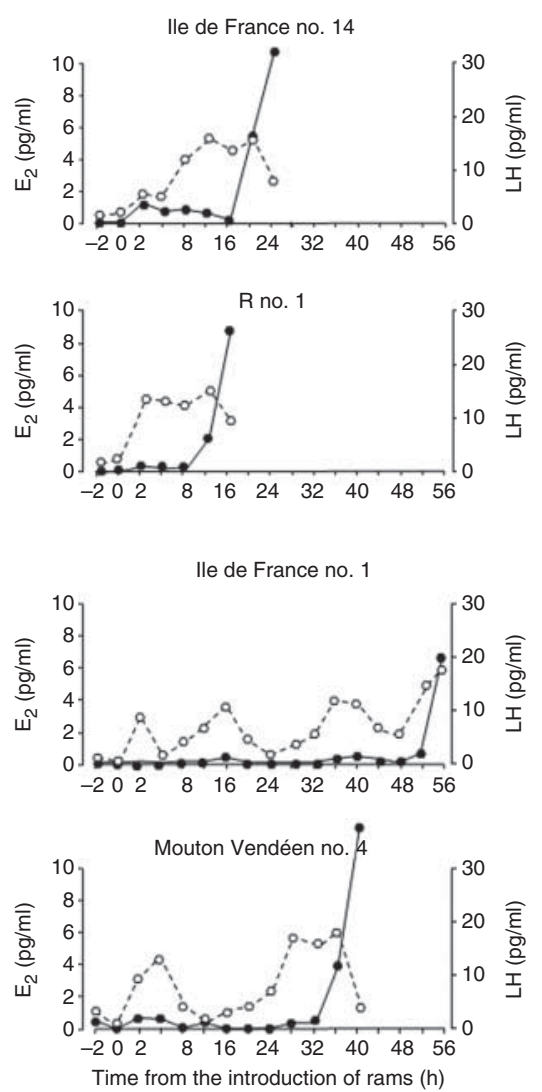

Figure 1 The pattern of concentrations of oestradiol ( $\mathrm{E}_{2}$; open circles, dotted lines) and $\mathrm{LH}$ (closed circles and solid lines) in anoestrous ewes after the introduction of sexually active rams at time 0 . Examples are shown of ewes that did not have a LH surge within the $56 \mathrm{~h}$ sampling window (Mouton Vendéen no. $1 \mathrm{~b}$ and $\mathrm{R}$ no. 2b) and of ewes with a LH surge and a continuous pattern of secretion of $E_{2}$ (Ile de France no. 14, $\mathrm{R}$ no. $1, \mathrm{M}$ nos 33 and 7 ), or a discontinous pattern of secretion of $E_{2}$ (lle de France no. 1 and Mouton Vendéen no. 4). 


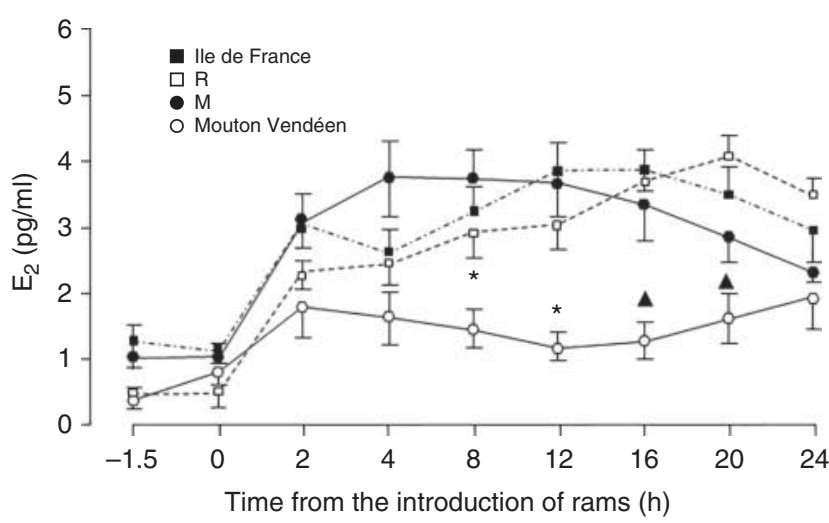

Figure 2 The pattern of concentrations of $E_{2}$ in four breeds of anoestrous ewes (Mouton Vendéen, $n=10$; Ile de France, $n=21 ; \mathrm{R}, n=18$ and $\mathrm{M}$, $n=18$ ) following exposure to a sexually active ram at time 0 . Data have been centred about time ' 0 ' (the introduction of rams) and are expressed as mean \pm S.E.M. Concentrations in Mouton Vendéen are lower than those in all other breeds $8,12 \mathrm{~h}$ after ram introduction (indicated by asterisks; $P<0.008$ ) and lower than Ile de France and $R$ at 16 and $20 \mathrm{~h}$ after male introduction (indicated by triangle; $P<0.004$ ). Statistical analyses were made using mixed model ANOVA under general linear model followed by paired comparisons between breeds using Bonferroni's correction.

the time of introduction of rams and the onset of the LH surge; otherwise $E_{2}$ concentration patterns were considered as 'continuous'. The data were then re-analysed after grouping them around the time of the peak of the LH surge. The quantity of $E_{2}$ secreted after the 'ram effect' was estimated from a plot of $E_{2}$ concentrations in plasma between the time of ram introduction and the maximum concentration of the $\mathrm{LH}$ surge as the area under this curve in $\mathrm{mm}^{2}$ using a triangulation procedure and from a baseline of 0 . An $\mathrm{LH}$ surge was defined as an increase in $\mathrm{LH}$, lasting at least $4 \mathrm{~h}$ and with a minimum of one value above $10 \mathrm{ng} / \mathrm{ml}$. The onset of the $\mathrm{LH}$ surge was defined as the first point preceding the sustained increase and when the $\mathrm{LH}$ concentration was at least three times the S.D. of the baseline (Moenter et al. 1990).

Statistical tests were carried out using SPSS version 20 (SPSS, Inc., IBM Company Headquarters). The data were tested for normality and when the data were not normally distributed they were either transformed to logarithms or analysed using non-parametric tests. The data involving measures over time were analysed using a mixed model ANOVA run under the general linear model with time as a repeated measure. Data from cell culture, RNA analyses and for the latency of the
LH surge were analysed using a univariate ANOVA run under the general linear model. For both types of ANOVA, post hoc paired comparisons within treatments were performed using the Bonferroni's correction if the ANOVA analysis showed an overall treatment effect that was significant. Overall and within breed correlations were tested using the non-parametric Spearman's rank test. The proportions were tested using the $\chi^{2}$ test. Differences were considered statistically significant when $P<0.05$ and as a trend toward significance when the $P$ value was between 0.05 and 0.10 .

\section{Results}

\section{The 'four breeds study'}

Eight examples (two from each breed) of the different patterns for the plasma concentration of $E_{2}$ and $\mathrm{LH}$ after introduction of rams are illustrated in Fig. 1. In all ewes $(67 / 67)$, the concentration of $E_{2}$ increased significantly following the introduction of rams, although the pattern and the magnitude of the increases were highly variable (Fig. 1). The statistical analysis showed that the concentrations increased after the introduction of rams $(P<0.001)$. The increase in $E_{2}$ concentrations was detected $2 \mathrm{~h}$ after ram introduction $(P<0.0001)$ and was greater in ewes that went on to have an LH surge than in ewes that did not $(1.98 \pm 0.25$ and $0.86 \pm 0.36 \mathrm{pg} / \mathrm{ml}$ respectively; $P<0.012$ ). In $65 \%$ of the ewes with an $\mathrm{LH}$ surge, there was a continuous pattern of increased $E_{2}$ (Fig. 1: IF, no. 14; R, no. 1 and $M$, nos 33 and 7) whereas in the other $35 \%$ had a discontinuous pattern of increased $E_{2}$ (Fig. 1: IF, no. 1 and $M V$, no. 4). In ewes with a surge starting between 8 and $56 \mathrm{~h}$ after introduction of rams, the mean plasma concentrations of $\mathrm{E}_{2}$ were above $2 \mathrm{pg} / \mathrm{ml}$ for $14.5 \pm 0.86 \mathrm{~h}(\mathrm{~min} 6 \mathrm{~h}$ and $\max 36 \mathrm{~h}$ ). There was no difference in the concentrations of $\mathrm{LH}$ before the onset of the LH surge (averaged for each ewe from the time of male introduction and the onset of the LH surge) between the ewes with a continuous $(1.23 \pm 0.10 \mathrm{ng} / \mathrm{ml})$ and a discontinuous $(1.39 \pm 0.23 \mathrm{ng} /$ $\mathrm{ml}$ ) pattern of secretion of $E_{2}$.

The concentrations of $E_{2}$ varied among breeds $(P<0.012$, Fig. 2) and the interaction between time and breed was significant $(P<0.001)$. Paired comparisons showed that the concentrations of $E_{2}$ in the MV ewes were significantly lower than those in IF

Table 2 The quantity of oestradiol (mean \pm S.E.M.) secreted after the 'ram effect' estimated as the area $\left(\mathrm{mm}^{2}\right)$ under the response curve between the time rams were introduced and the time of maximum concentration of LH and latency of the onset of the LH surge (h) in ewes with a surge or between the time rams were introduced and $56 \mathrm{~h}$ in ewes without a $\mathrm{LH}$ surge.

\begin{tabular}{|c|c|c|c|c|}
\hline & \multicolumn{4}{|c|}{ Breed of ewe } \\
\hline & Ile de France & M & $\begin{array}{l}\text { Mouton } \\
\text { Vendéen }\end{array}$ & $\mathrm{R}$ \\
\hline Area under the curve $\left(\mathrm{mm}^{2}\right)$ in ewes with a LH surge & $68 \pm 9.7^{\mathrm{a}, \mathrm{b}}(18)$ & $54 \pm 6.1^{\mathrm{a}}(17)$ & $86 \pm 17.1^{\mathrm{a}, \mathrm{b}}(7)$ & $102 \pm 12.8^{\mathrm{b}}(15)$ \\
\hline Mean latency of the surge $(h)$ & $20.8 \pm 3.39^{\mathrm{a}, \mathrm{c}}$ & $16.9 \pm 2.04^{\mathrm{a}}$ & $40.6 \pm 4.22^{\mathrm{b}, \mathrm{c}}$ & $31.2 \pm 4.217^{\mathrm{c}}$ \\
\hline Area under the curve $\left(\mathrm{mm}^{2}\right)$ in ewes without LH surge & $99 \pm 18.4^{\mathrm{a}, \mathrm{b}}(3)$ & $120(1)$ & $32 \pm 11.4^{\mathrm{a}}(3)$ & $73 \pm 10.3^{\mathrm{a}, \mathrm{b}}(3)$ \\
\hline
\end{tabular}

The value in brackets indicates the number of ewe per group. Values with a different superscript are significantly different at a $P$ value of 0.05 . 


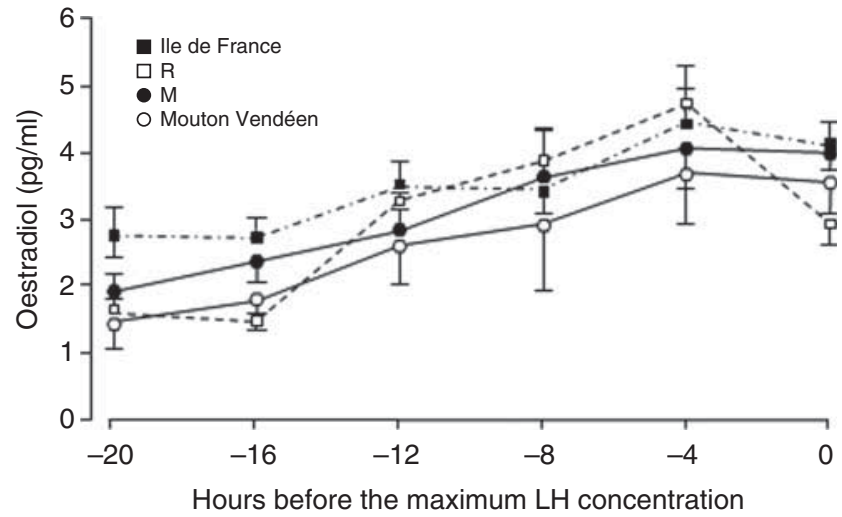

Figure 3 The pattern of concentrations of oestradiol in four breeds of anoestrous ewes (Mouton Vendéen, $n=7$; Ile de France, $n=18 ; \mathrm{R}$, $n=15$ and $M, n=17$ ) following exposure to a sexually active ram. Data have been centred around the time when the maximum concentration of $\mathrm{LH}$ was observed (time 0 ) and are expressed as mean \pm S.E.M. Statistical analysis were made using mixed model ANOVA under general linear model and showed an effect of time $(P<0.037)$ but no effect of breed and no interaction of time and breed.

$(P<0.051), \quad R \quad(P<0.011)$ and $M$ ewes $(P<0.011)$. The concentrations in $R, I F$ and $M$ ewes did not differ. The proportion of MV ewes (0/7) with a 'continuous' pattern of $E_{2}$ concentrations was lower than that in IF $(14 / 18 ; P<0.001), M(13 / 17 ; P<0.001)$ and $\mathrm{R}(10 / 15$; $P=0.003)$ ewes. There were no differences in proportions among IF, $\mathrm{M}$ and $\mathrm{R}$ ewes with 'continuous' pattern of $\mathrm{E}_{2}$.

The quantity of $E_{2}$ secreted after the introduction of rams, estimated from the area under the curve, varied with breed $(P<0.001$, Table 2$)$. R ewes with a LH surge secreted significantly more $E_{2}(P<0.001)$ than $M$ with a LH surge. IF, M and MV did not differ.

The latency to the LH surge was longer in MV than in IF ewes $(P<0.01)$ and $\mathrm{M}(P<0.001)$, but $\mathrm{R}$ only differed significantly from $M$ ewes $(P<0.02$, Table 2$)$. The area under the $E_{2}$ curve was correlated with the latency to the LH surge both when pooled among breeds $(r=0.779$; $P<0.0001$ ) and by breed (IF: $r=0.932 ; P<0.001 ; M$ : $r=0.6293 ; P<0.01 ; \mathrm{MV}: r=0.7456 ; P<0.05$ and $\mathrm{R}$ : $r=0.8304 ; P<0.001)$. In ewes that did not have an $\mathrm{LH}$ surge within the $56 \mathrm{~h}$ sampling period, the area under the $E_{2}$ curve did not differ significantly from those with an LH surge, although for the MV breed it tended to be lower $(P=0.08)$.

Analysis of the concentrations of $E_{2}$ grouped around the maximum concentration of LH (Fig. 3) showed a significant effect of time $(P=0.037)$, but no effect of breed and no interaction of time with breed. In all ewes that had a surge later than $8 \mathrm{~h}$ after the introduction of rams $(n=52)$, the concentration of $E_{2}$ in plasma $4 \mathrm{~h}$ before the LH surge exceeded $2.5 \mathrm{pg} / \mathrm{ml}$ (IF, $5.11 \pm$ $0.40 \mathrm{pg} / \mathrm{ml} ; \mathrm{M}, 4.47 \pm 0.42 \mathrm{pg} / \mathrm{ml} ; \mathrm{MV}, 3.73 \pm 0.82 \mathrm{pg} /$ $\mathrm{ml}$ and $\mathrm{R}, 4.73 \pm 0.56 \mathrm{pg} / \mathrm{ml}$ ) and in most ewes $(41 / 57)$ the mean concentration at $0 \mathrm{~h}$ was lower $(P<0.0001)$ than at $-4 \mathrm{~h}(3.73 \pm 0.20 \mathrm{pg} / \mathrm{ml}$ vs $4.60 \pm 0.27 \mathrm{pg} / \mathrm{ml})$.

\section{The ovarian response study}

The effects of exposure to either unfamiliar ewes (controls) or sexually active rams on the number of ovarian follicles are presented in Table 3. Exposure to a ram 2 or $12 \mathrm{~h}$ had no effect on the number of follicles in any size category present on the ovaries compared with those on ovaries of ewes exposed to unfamiliar ewes for $2 \mathrm{~h}$ in either the MV or IF ewes. But in IF ewes, the number of SFs tended to differ $(P=0.062)$ and paired comparisons showed that the $12 \mathrm{~h}$ group was significantly different from the $2 \mathrm{~h}$ group $(P=0.021)$. This tendency was not observed in $\mathrm{MV}$ ewes.

The in vitro production of $\mathrm{E}_{2}$ by cultured granulosa cells was higher $(P<0.001)$ in IF ewes exposed to rams for $12 \mathrm{~h}$ (Fig. 4, top panel) compared with those exposed to rams for $2 \mathrm{~h}$. But in vitro concentrations of $\mathrm{E}_{2}$ did not differ between IF ewes exposed to rams for $2 \mathrm{~h}$ compared with those exposed for $2 \mathrm{~h}$. The conditions of culture also affected $\mathrm{E}_{2}$ output by the cultured granulosa cells from IF ewes and all culture treatments were significantly different from the others (all paired comparison $P<0.001$ ). The order from the lowest to highest production of $\mathrm{E}_{2}$ was controls $<$ IGF1 $<$ FSH $<$ (FSH + IGF1) (Fig. 4, top panel).

Table 3 The effect of exposure to a ram for $2 \mathrm{~h}$ (male $2 \mathrm{~h}$ ) or $12 \mathrm{~h}$ (male $12 \mathrm{~h}$ ) or to an unfamiliar ewe (control) on the total number of ovarian follicle $>1.0 \mathrm{~mm}$ in diameter (mean \pm S.E.M.) and the number of small (diameter: 1.0-2.0 mm), medium (diameter: $<2.0-3.5 \mathrm{~mm}$ ) and large (diameter: $<3.5 \mathrm{~mm}$ ) follicles in anoestrus Ile de France and Mouton Vendéen ewes (mean \pm s.E.M.).

\begin{tabular}{|c|c|c|c|c|}
\hline \multirow[b]{2}{*}{ Treatment } & \multicolumn{4}{|c|}{ Classification of follicles } \\
\hline & Total & Small & Medium & Large \\
\hline \multicolumn{5}{|l|}{ Ile de France } \\
\hline Control $(n=6)$ & $24.0 \pm 2.9$ & $22.2 \pm 2.9$ & $0.5 \pm 0.4$ & $1.3 \pm 0.5$ \\
\hline Male $2 \mathrm{~h}(n=6)$ & $29.8 \pm 2.9$ & $27.5 \pm 4.7$ & $1 \pm 0.3$ & $1.3 \pm 0.5$ \\
\hline \multirow{2}{*}{\multicolumn{5}{|c|}{ Vendéen }} \\
\hline & & & & \\
\hline Control $(n=4)$ & $32.5 \pm 1.1$ & $28.8 \pm 5.4$ & $2.8 \pm 1.2$ & $1.0 \pm 0.5$ \\
\hline Male $2 \mathrm{~h}(n=4)$ & $29.8 \pm 9.2$ & $27.0 \pm 9.4$ & $1 \pm 0.7$ & $1.0 \pm 0.8$ \\
\hline Male $12 \mathrm{~h}(n=3)$ & $41.0 \pm 3.1$ & $39.3 \pm 14.2$ & 0.0 & $1.3 \pm 0.6$ \\
\hline
\end{tabular}

In both breeds, there was no effect of treatment on the number of follicles. However, there was a trend towards significance in Ile de France ewes $(P=0.062)$ and paired comparison showed a lower number of small follicles in the male $12 \mathrm{~h}$ group than in the male $2 \mathrm{~h}$ group $\left({ }^{*} P<0.021\right)$. 

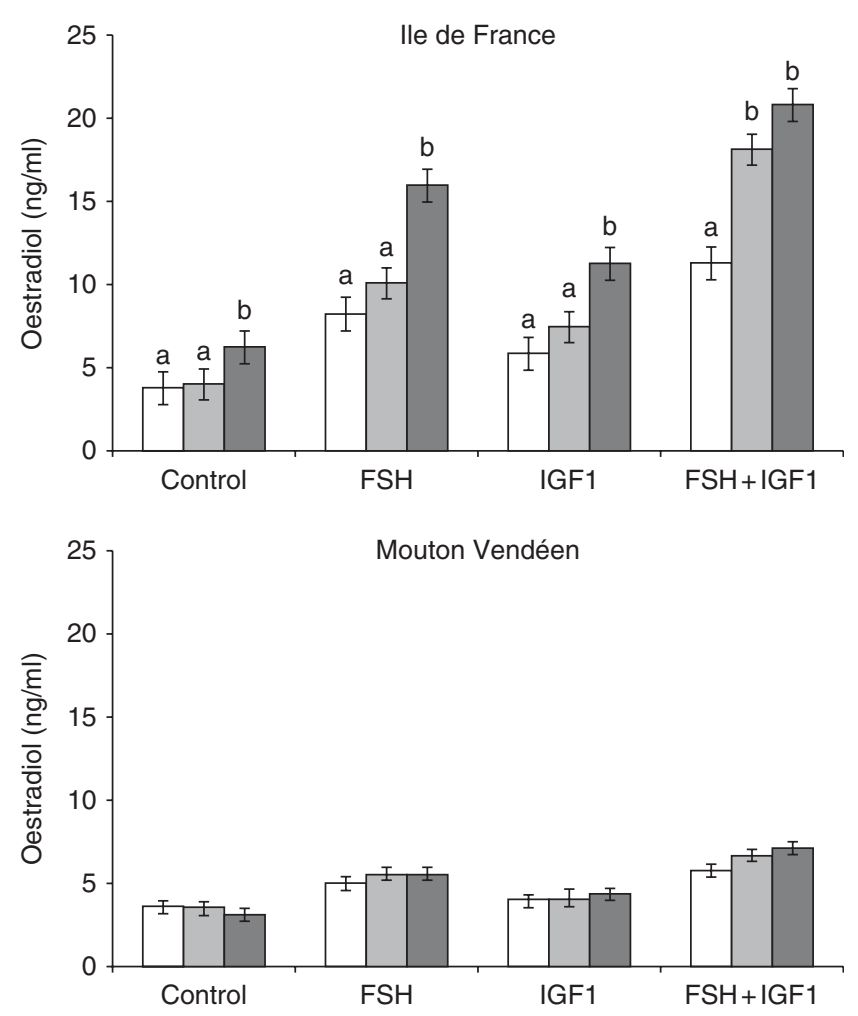

Figure 4 The effect of exposure for $2 \mathrm{~h}$ to an unfamiliar ewe (control; light grey columns) or to a sexually active ram for either $2 \mathrm{~h}$ (medium grey columns) or $12 \mathrm{~h}$ (dark grey columns) on oestradiol secretion in vitro by granulosa cells from anoestrous Ile de France (top panel, $n=6$ ) or Mouton Vendéen (bottom panel, $n=4$ ) ewes after $48 \mathrm{~h}$ culture in enriched McCoy's 5A medium (without FCS) and in the absence (control) or presence of FSH $\left(10^{-8} \mathrm{M}\right)$, IGF1 $\left(10^{-8} \mathrm{M}\right)$ or IGF1 + FSH (both $10^{-8} \mathrm{M}$ ). Steroid secretion was normalised against the protein concentration of each well. Results are presented as mean \pm s.E.M. Within the in vitro treatment groups, different letters indicate significant differences $(P<0.05$ univariate ANOVA under general linear model). There were no significant differences within the in vitro treatment groups for the Mouton Vendéen ewes.

In MV ewes, there were no significant differences among the three groups (Fig. 4, bottom panel) either among the control cultures or the cells cultured with FSH, IGF1 or both (Fig. 4, bottom panel).

The in vitro production of progesterone by cultured granulosa cells was higher in IF ewes exposed to rams for $12 \mathrm{~h}$ (Fig. 5, top panel) compared with those exposed to rams for $2 \mathrm{~h}(P<0.001)$, but progesterone concentrations were not different in ewes exposed to rams vs ewes for $2 \mathrm{~h}$. Similar to $E_{2}$ concentrations, the conditions of culture also affected progesterone output by the cultured granulosa cells from IF ewes. And all culture treatments were significantly different from the others (all paired comparison $P<0.001)$. The order from the lowest to highest production of progesterone was controls $<\mathrm{IGF} 1<\mathrm{FSH}<(\mathrm{FSH}+\mathrm{IGF1}$ ) (Fig. 5, top panel). In $\mathrm{MV}$ ewes, there were no significant differences among the three groups (Fig. 5, bottom panel) either among the control cultures or the cells cultured with FSH, IGF1 or both (Fig. 5, bottom panel).

The level of mRNA for StAR was higher in IF ewes exposed to rams for $12 \mathrm{~h}$ compared with those in IF ewes exposed to either other ewes $(P<0.001)$ or to rams $(P<0.001)$ for $2 \mathrm{~h}$ (Fig. 6, top panel). However, in the $M V$ ewes, the level of the STAR mRNA expression was similar in ewes exposed to ewes for $2 \mathrm{~h}$ or exposed to rams for 2 or $12 \mathrm{~h}$ (Fig. 6, bottom panel). In both IF and MV ewes, the mRNA expression of $H S D 3 B$ and CYP11A1 was not affected by exposure to ewes for $2 \mathrm{~h}$ or exposure to rams for 2 or $12 \mathrm{~h}$ (Fig. 6).

\section{Discussion}

Our results show that in most anoestrous ewes, the $\mathrm{LH}$ surge induced by the socio-sexual stimulus of introduction of rams is preceded by an increase in circulating concentrations of $E_{2}$ for between 8 and $56 \mathrm{~h}$ after the introduction of rams. The duration and the pattern of
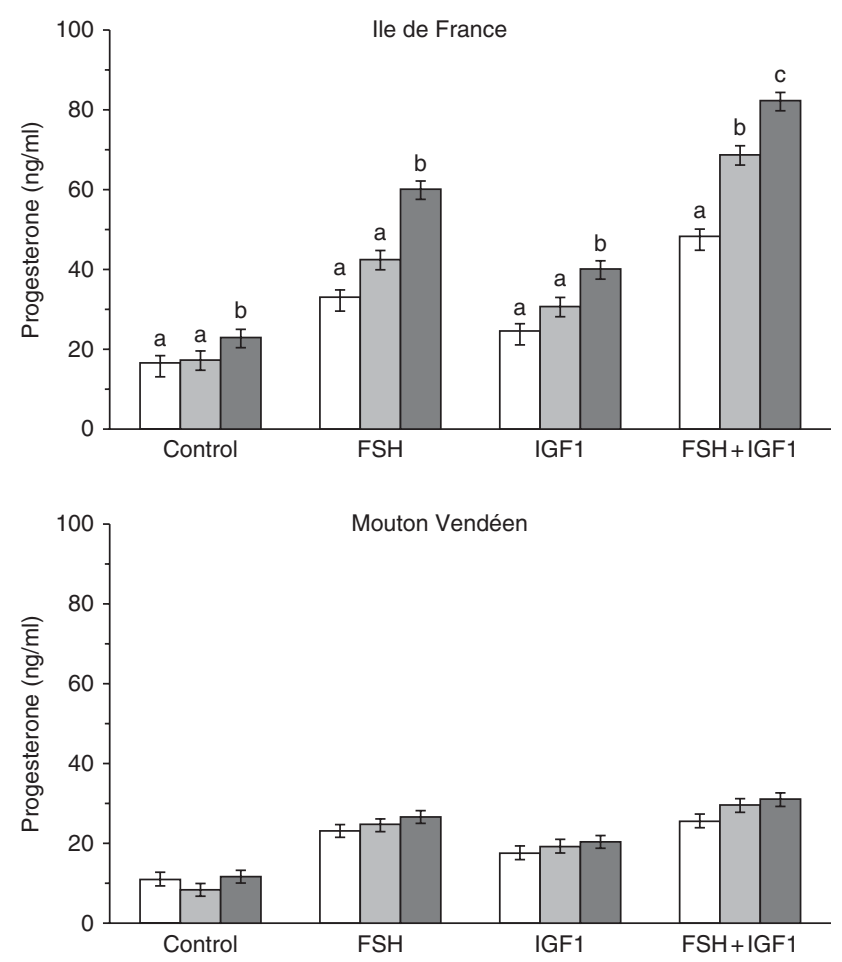

Figure 5 The effect of exposure for $2 \mathrm{~h}$ to an unfamiliar ewe (control; light grey columns) or to a sexually active ram for either $2 \mathrm{~h}$ (medium grey columns) or $12 \mathrm{~h}$ (dark grey columns) on progesterone secretion in vitro by granulosa cells from anoestrous Ile de France (top panel, $n=6$ ) or Mouton Vendéen (bottom panel, $n=4$ ) ewes after $48 \mathrm{~h}$ culture in enriched McCoy's 5A medium (without FCS) and in the absence (control) or presence of FSH $\left(10^{-8} \mathrm{M}\right)$, IGF1 $\left(10^{-8} \mathrm{M}\right)$ or IGF1 + FSH (both $10^{-8} \mathrm{M}$ ). Steroid secretion was normalised against the protein concentration of each well. Results are presented as mean \pm s.E.M. Within the in vitro treatment groups, different letters indicate significant differences $(P<0.05$ univariate ANOVA under general linear model). There were no significant differences within the in vitro treatment groups for the Mouton Vendéen ewes. 

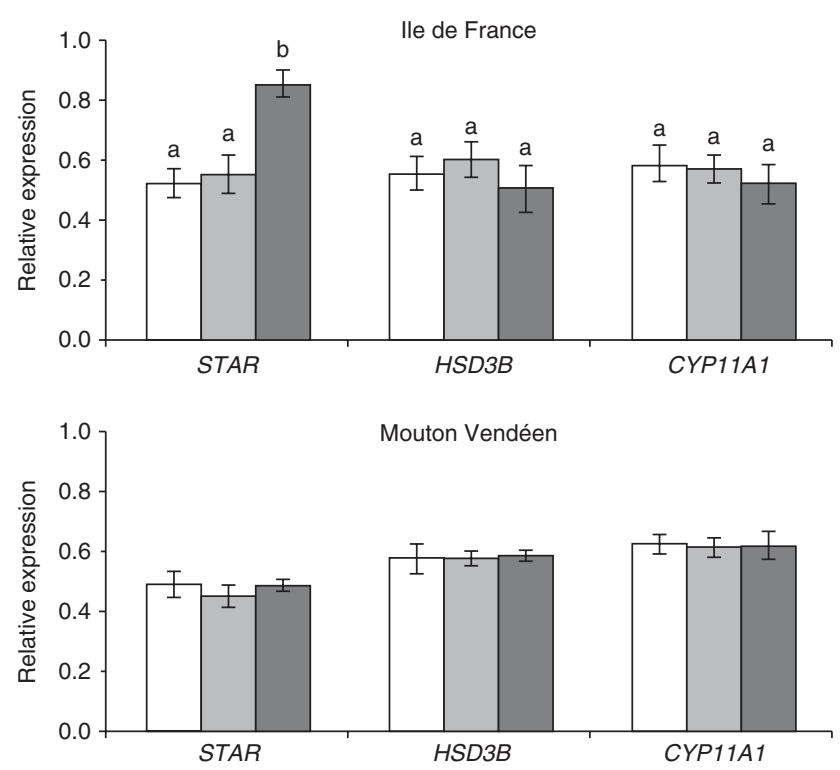

Figure 6 The expression of mRNA in ovine granulosa cells from anoestrous Ile de France (top panel) or Mouton Vendéen (bottom panel) ewes exposed for $2 \mathrm{~h}$ to an unfamiliar ewe (control; light grey columns: IF, $n=6$ and $M V, n=4$ ) or to a sexually active ram for either $2 \mathrm{~h}$ (medium grey columns: IF, $n=6$ and $M V, n=4$ ) or $12 \mathrm{~h}$ (dark grey columns: IF, $n=6$ and MV, $n=3$ ). Total mRNA was extracted from granulosa cells and reverse transcribed and real-time RT-PCR was performed. The geometric mean of three housekeeping genes (PPIA, RPL19 and ACTB) was used to normalise gene expression. Results are presented as mean \pm S.E.M. Different letters indicate significant differences $(P<0.05$ univariate ANOVA under general linear model).

these increases were variable and some of the variability appears to be associated with the breed of ewe. In our previous experiment, we showed that ram-induced pulsatile secretion of $\mathrm{LH}$ did not differ among breeds (Chanvallon et al. 2011). In the MV breed, the variability in the response to the 'ram effect' seemed to be caused primarily by a reduced ovarian response to $\mathrm{LH}$ resulting in lower concentrations of $E_{2}$ in plasma and presence of LH surges at a lower frequency and/or a longer latency. However, in $R$ ewes, the plasma concentrations of $E_{2}$ after the introduction of rams were not higher than that in IF or $M$ ewes; However, the quantity of $E_{2}$ secreted (estimated as the area under the curve) before the $\mathrm{LH}$ surge was higher in the $\mathrm{R}$ breed, suggesting that the variability in this breed was due to a lower sensitivity of the hypothalamo-hypophyseal complex to the positive feedback effect of $E_{2}$.

In all ewes, the concentration of $E_{2}$ increased within $4 \mathrm{~h}$ of the 'ram effect'. Large follicles are the predominant source of $E_{2}$ in ewes (Baird \& Scaramuzzi 1976). These follicles secrete $E_{2}$ following each pulse of $\mathrm{LH}$ both in the breeding season (Baird et al. 1976) and in anoestrus (Scaramuzzi \& Baird 1977). There were large follicles (>3.5 $\mathrm{mm}$ diameter) present in most ewes (Table 3). The increased concentration of $E_{2}$ following the 'ram effect' is undoubtedly the result of increased pulsatile secretion of $\mathrm{LH}$ that in itself is a response to the sociosexual stimulation that always follows exposure to an unfamiliar sexual partner (Hawken et al. 2007, Chanvallon et al. 2011, Jorre de St Jorre et al. 2012). Sheep have particularly low concentrations of blood $E_{2}$, especially during anoestrus, and present considerable technical difficulties when attempting to assay the circulating concentrations of $E_{2}$. Consequently, until recently there has been little detailed analysis of the concentrations of circulating $E_{2}$ in the anoestrous ewes ovulating in response to the introduction of rams. One report from our group (Johnson et al. 2011) showed that the plasma concentrations of $\mathrm{E}_{2}$ increased $8 \mathrm{~h}$ after the introduction of rams and that the occurrence of the $\mathrm{LH}$ surge in response to socio-sexual stimulation was strongly related to the concentration of $E_{2}$ during the $48 \mathrm{~h}$ following the introduction of ram. In addition, there have been a number of reports in the males of several species, where exposure to females increased $\mathrm{LH}$ secretion and that this was followed by increased testosterone secretion (Katongole et al. 1971, Rose et al. 1972, Kamel et al. 1975, Gonzalez et al. 1988). Thus, a neuro-endocrine response to socio-sexual stimulation seems to be a common physiological mechanism allowing animals to adapt to socio-sexual conditions. Interestingly, this was also the case in ewes that did not go on to have a LH surge, suggesting that the immediate increase in the pulsatile secretion of $\mathrm{LH}$ following sociosexual stimulation and the following LH surge, although closely associated, are distinct phenomena. In an earlier study (Chanvallon et al. 2011), we were able to show that a short-term increase in the pulsatile secretion of $\mathrm{LH}$ following the introduction of a ram was an almost universal response occurring in 104 out of 112 ewes $(93 \%)$. In this study, the short-term response was not always followed by a LH surge and only 71 (68\%) went on to have a LH surge. This study extends these observations and shows that the short-term increase in pulsatile LH induced by the 'ram effect' is consistently followed by an increase in follicular $E_{2}$ secretion but that the temporal pattern and duration of the increase in the concentration of $E_{2}$ is variable.

In about two thirds of the ewes with a LH surge, the concentrations of $E_{2}$ remained elevated from the time of the 'ram effect' until the LH surge (continuous responses), an interval of between 8 and $56 \mathrm{~h}$. In the other third, the concentrations of $E_{2}$ were more variable (discontinuous responses), with several episodes of increased concentrations of $E_{2}$ before the LH surge. These patterns are very similar to those seen before the LH surge in cyclic ewes (Baird et al. 1976) and in other spontaneous ovulators such as the rat (Smith et al. 1975) and the rhesus monkey (Hotchkiss et al. 1971), and suggests that the ram-induced $\mathrm{LH}$ surge is a consequence of $E_{2}$-positive feedback (see review by Goodman (1994)). We did not find any significant difference in the concentrations of $\mathrm{LH}$ between ewes 
with continuous or discontinuous patterns of secretion of $E_{2}$. The discontinuous patterns of secretion of $E_{2}$ differed among breeds and this pattern was seen in all the ewes of the MV breed and ewes of this breed also had lower concentrations of $E_{2}$ suggesting reduced ovarian responses to the introduction of rams.

Cultured granulosa cells secreted both $E_{2}$ and progesterone. Those from IF ewes responded to both socio-sexual stimulation for $12 \mathrm{~h}$ and also to the addition of FSH and IGF1, known stimulants of granulosa cells steroidogenesis (Campbell et al. 1996). There is an extensive literature on the effects of IGF1 and FSH both alone and in combination on the secretion of $E_{2}$ by cultured granulosa cells from various species (Campbell et al. 1996, 2003, Spicer et al. 2002) and our data show close agreement with this literature. The ability of cultured granulosa cells from the IF breed to respond to FSH and IGF1 was associated with increased levels of STAR mRNA, suggesting a key role of this step in the response to the 'ram effect'. Cultured granulosa cells from the MV breed behaved very differently, they were completely non-responsive to either socio-sexual stimulation or to stimulation by FSH, IGF1 or a combination of both. The low levels of STAR of MV anoestrous ewes may compromise their ability to secrete $E_{2}$ in response to the 'ram effect' and could be responsible for the generally poorer responses to the 'ram effect' than other breeds (Chanvallon et al. 2011).

When the data for $E_{2}$ were centred around the time of the $\mathrm{LH}$ surge rather than the time when the rams were introduced, the concentrations of $\mathrm{E}_{2}$ in the $20 \mathrm{~h}$ before the $\mathrm{LH}$ surge were still higher than baseline, but the breed difference were no longer significant. This apparent contradiction can be explained first by the longer latency between the introduction of the rams and the start of the LH surge in some breed (R and MV). It can also be explained by the fact that in all animals with $\mathrm{LH}$ surges, the concentration of $\mathrm{E}_{2}$ exceeded the threshold concentration for positive feedback. In cyclic ewes, the amount of $E_{2}$ required for induction and maintenance of the $\mathrm{LH}$ surge has been defined by studies in ovariectomised, $\mathrm{E}_{2}$-treated ewes, and is much lower than that normally present in intact cyclic ewes during the follicular phase of the oestrous cycle (Evans et al. 1997).

Similarly to intact ewes (Karsch et al. 1979), the mean concentrations of $E_{2}$ in most ewes were lower $4 \mathrm{~h}$ after the maximum concentrations of the $\mathrm{LH}$ surge than at the peak of the LH surge. This suggests that the feedback regulations of the ovary during anoestrus are identical to those during the breeding season.

The total amount of $E_{2}$ present before the $\mathrm{LH}$ surge was positively correlated with the latency of the LH surge and differed among breeds; the $\mathrm{R}$ breed required more $E_{2}$ before the $\mathrm{LH}$ surge than the $M$ breed. Similar breed differences in the concentration of $E_{2}$ before the surge have been observed during the breeding season and have often been linked with the prolificity of the breed (Land et al. 1976, Cahill et al. 1981). In one study using both intact and ovariectomised ewes, Ben Saïd et al. (2007) showed that Romanov ewes, a breed that has multiple ovulations, require higher concentrations of $E_{2}$ and for a longer duration for the induction of a LH surge than IF ewes. The R is a breed developed from a cross between Romanov and Berrichon du Cher breeds. The $\mathrm{R}$ had a higher quantity of $\mathrm{E}_{2}$ before the LH surge compared with $M$ ewes, but the concentrations of $E_{2}$ after the introduction of rams were not different compared with other breeds. This suggests a higher threshold concentration and longer duration of exposure to $E_{2}$ are required to induce an $\mathrm{LH}$ surge as observed previously in Romanov breed (Ben Saïd et al. 2007). This probably explains why $R$ sheep that are less seasonal (Chanvallon et al. 2011) have more variable responses to the introduction of rams compared with the equally less seasonal $M$ sheep.

In $\mathrm{MV}$ ewes the time required to reach the threshold concentration of $E_{2}$ for the induction of the $\mathrm{LH}$ surge was longer than for the other breeds, thus explaining the longer latency in this breed. The levels of STAR mRNA expression were higher in IF ewes exposed to the male for $12 \mathrm{~h}$, but this was not the case for MV. This finding is consistent with the findings from the culture experiments and the blood concentrations of $E_{2}$ because STAR is an essential step and rate-limiting step in steroidogenesis (Clark \& Stocco 1996). In an earlier study, we have shown that STAR mRNA in the granulose cells of follicles from anoestrous ewes was increased by pre-treatment with progesterone (Brown et al. 2014) a treatment known to improve the response to the 'ram effect'. The synthesis of STAR in the ovary is stimulated rapidly by LH (Selvaraj et al. 1996, Light \& Hammes 2013) and following the 'ram effect' there is a rapid increase in the secretion of pulsatile $\mathrm{LH}$. Taken together these data suggest that the inability of follicles in the ovaries of anoestrous ewes to synthesise STAR is a major reason for the variability of the response to the 'ram effect'. This result could explain the poor response of the MV.

In conclusion, our study shows that the presence or absence of an $\mathrm{LH}$ surge and therefore an ovulation after the socio-sexual stimulus of the 'ram effect' are linked with the ability of the ovary to synthesise STAR and thus secrete sufficient $E_{2}$ in response to the maleinduced increased in LH pulsatility and in the ability to cause a preovulatory surge in response to this increase in $E_{2}$.

\section{Declaration of interest}

The authors declare that there is no conflict of interest that could be perceived as prejudicing the impartiality of the research reported. 


\section{Funding}

The research was supported by grants from the Région Centre (DURAREP; 200800030333 and DURAREP 2; 2011 00064290) and the European Union Framework 6 funding program (MEXC-CT-2006-042499). R J Scaramuzzi was the recipient of an EU Marie Curie Chair of Excellence (MEXC-CT2006-042499). A Chanvallon was the recipient of a PhD studentship jointly funded by the 'Convention Industrielle de Formation par la Recherche', the 'Centre Interrégional $d^{\prime}$ Information et de Recherche en Production Ovine' and the 'Association Nationale de la Recherche et de la Technologie'.

\section{Acknowledgements}

The authors wish to thank the staff from INRA experimental stations in Nouzilly, Bourges and Frejorgues for the care of the animals and for their help during the experiments. They would also like to thank several MSc students, S Bertaux, C Buron, M David, A Durand, J Gauthier, C Journault, A Pelletier and O Robineau, who participated in various aspects of these experiments.

\section{References}

Baird DT \& Scaramuzzi RJ 1976 The source of ovarian oestradiol and androstenedione in the sheep during the luteal phase. Acta Endocrinologica 83 402-409.

Baird DT, Swanston I \& Scaramuzzi RJ 1976 Pulsatile release of LH and secretion of ovarian steroids in sheep during the luteal phase of the estrous cycle. Endocrinology 98 1490-1496. (doi:10.1210/endo-98-61490)

Ben Saïd S, Lomet D, Chesneau D, Lardic L, Canepa S, Guillaume D, Briant C, Fabre-Nys C \& Caraty A 2007 Differential estradiol requirement for the induction of estrus behavior and the luteinizing hormone surge in two breeds of sheep. Biology of Reproduction 76 673-680. (doi:10.1095/ biolreprod.106.057406)

Brown HM, Fabre-Nys C, Cognié J \& Scaramuzzi RJ 2014 Short oestrous cycles in sheep during anoestrus involve defects in progesterone biosynthesis and luteal neovascularisation. Reproduction 147 357-367. (doi:10.1530/REP-13-0400)

Cahill LP, Saumande J, Ravault JP, Blanc M, Thimonier J, Mariana JC \& Mauléon P 1981 Hormonal and follicular relationships in ewes of high and low ovulation rates. Journal of Reproduction and Fertility 62 141-150. (doi:10.1530/jrf.0.0620141)

Campbell BK, Scaramuzzi RJ \& Webb R 1996 Induction and maintenance of oestradiol and immunoreactive inhibin production with $\mathrm{FSH}$ by ovine granulosa cells cultured in serum free media. Journal of Reproduction and Fertility 106 7-16. (doi:10.1530/jrf.0.1060007)

Campbell BK, Souza C, Gong J, Webb R, Kendall N, Marsters P, Robinson G, Mitchell A, Telfer EE \& Baird DT 2003 Domestic ruminants as models for the elucidation of the mechanisms controlling ovarian follicle development in humans. Reproduction Supplement 61 429-443.

Canepa S, Laine AL, Bluteau A, Fagu C, Flon C \& Monniaux D 2008 Validation d'une méthode immunoenzymatique pour le dosage de la progestérone dans le plasma des ovins et des bovins. Cahiers Techniques de I'INRA 64 19-30.

Chanvallon A, Sagot L, Pottier E, Debus N, François D, Fassier T, Scaramuzzi RJ \& Fabre-Nys C 2011 New insights into the influence of breed and time of the year on the response of ewes to the 'ram effect'. Animal 5 1594-1604. (doi:10.1017/S1751731111000668)

Clark BJ \& Stocco DM 1996 StAR - a tissue specific acute mediator of steroidogenesis. Trends in Endocrinology and Metabolism 7 227-233. (doi:10.1016/S1043-2760(96)00114-2)

Corker CS, Naftolin F \& Exley D 1969 Interrelationship between plasma luteinizing hormone and oestradiol in the human menstrual cycle. Nature 222 1063. (doi:10.1038/2221063a0)
Evans NP, Dahl GE, Padmanabhan V, Thrun LA \& Karsch FJ 1997 Estradiol requirements for induction and maintenance of the gonadotropinreleasing hormone surge: implications for neuroendocrine processing of the estradiol signal. Endocrinology 138 5408-5414. (doi:10.1210/ endo.138.12.5558)

Faure MO, Nicol L, Fabre S, Fontaine J, Mohoric N, McNeilly A \& Taragnat C 2005 BMP-4 inhibits follicle-stimulating hormone secretion in ewe pituitary. Journal of Endocrinology 186 109-121. (doi:10.1677/joe.1.05988)

Gonzalez R, Orgeur P \& Signoret JP 1988 Luteinizing hormone, testosterone and cortisol responses in rams upon presentation of estrous females in the non-breeding season. Theriogenology 30 1075-1086. (doi:10.1016/0093-691X(88)90282-8)

Goodman RL 1994 Neuroendocrine control of the ovine estrous cycle. In The Physiology of Reproduction, 2nd edn, pp 659-709. Eds E Knobil \& JD Neill. New York: Raven Press.

Hauger RL, Karsch FJ \& Foster DL 1977 A new concept for control of the estrous cycle of the ewe based on the temporal relationships between luteinizing hormone, estradiol and progesterone in peripheral serum and evidence that progesterone inhibits tonic LH secretion. Endocrinology 101 807-817. (doi:10.1210/endo-101-3-807)

Hawken PA, Beard AP, Esmaili T, Kadokawa H, Evans AC, Blache D \& Martin GB 2007 The introduction of rams induces an increase in pulsatile LH secretion in cyclic ewes during the breeding season. Theriogenology 68 56-66. (doi:10.1016/j.theriogenology.2007.03.023)

Hotchkiss J, Atkinson LE \& Knobil E 1971 Time course of serum estrogen and luteinizing hormone (LH) concentrations during the menstrual cycle of the rhesus monkey. Endocrinology 89 177-183. (doi:10.1210/endo89-1-177)

Johnson L, Fabre-Nys C, Chanvallon A, François D, Fassier T, Menassol JB, Brown HM, Lardic L \& Scaramuzzi RJ 2011 The effect of short-term nutritional supplementation and body condition score on the ovarian responses of anoestrous ewes to the "ram effect". Journal of Veterinary Science and Technology S2 001. (doi:10.4172/2157-7579.S2-001)

Jorre de St Jorre T, Hawken PA \& Martin GB 2012 Role of male novelty and familiarity in male-induced LH secretion in female sheep. Reproduction, Fertility, and Development 24 523-530. (doi:10.1071/RD11085)

Kamel F, Mock EJ, Wright WW \& Frankel Al 1975 Alterations in plasma concentrations of testosterone, $\mathrm{LH}$, and prolactin associated with mating in the male rat. Hormones and Behavior 6 277-288. (doi:10.1016/0018506X(75)90014-8)

Karsch FJ, Weick RF, Butler WR, Dierschke DJ, Krey LC, Weiss G, Hotchkiss J, Yamaji T \& Knobil E 1973 Induced LH surges in the rhesus monkey: strength-duration characteristics of the estrogen stimulus. Endocrinology 92 1740-1747. (doi:10.1210/endo-92-6-1740)

Karsch FJ, Foster DL, Legan SJ, Ryan KD \& Peter GK 1979 Control of the pre-ovulatory endocrine events in the ewe: interrelationship of estradiol, progesterone, and luteinizing hormone. Endocrinology 105 421-426. (doi:10.1210/endo-105-2-421)

Katongole CB, Naftolin F \& Short RV 1971 Relationship between blood levels of luteinizing hormone and testosterone in bulls, and the effects of sexual stimulation. Journal of Endocrinology $\mathbf{5 0} 457-466$. (doi:10.1677/ joe.0.0500457)

Knight TW, Petersen AJ \& Payne E 1978 The ovarian and hormonal response of the ewe to stimulation by the ram early in the breeding season. Theriogenology 10 343-348. (doi:10.1016/0093-691X(78)90038-9)

Land RB, Wheeler AG \& Carr WR 1976 Seasonal variation in the oestrogen induced LH discharge on ovariectomized Finnish Landrace and Scottish Blackface ewes. Annales de Biologie Animale, Biochimie, Biophysique 16 521-528. (doi:10.1051/rnd:19760402)

Light A \& Hammes SR 2013 Membrane receptor cross talk in steroidogenesis: recent insights and clinical implications. Steroids 78 633-638. (doi:10.1016/j.steroids.2012.12.016)

Martin GB, Oldham CM, Cognie Y \& Pearce DL 1986 The physiological responses of anovulatory ewes to the introduction of rams - a review. Livestock Production Science 15 219-247. (doi:10.1016/0301-6226(86)90031-X)

Martin GB, Milton JT, Davidson RH, Banchero Hunzicker GE, Lindsay DR \& Blache D 2004 Natural methods for increasing reproductive efficiency in small ruminants. Animal Reproduction Science 82-83 231-245. (doi:10.1016/j.anireprosci.2004.05.014)

Moenter SM, Caraty A \& Karsch FJ 1990 The estradiol-induced surge of gonadotropin-releasing hormone in the ewe. Endocrinology 127 1375-1384. (doi:10.1210/endo-127-3-1375) 
Oldham CM, Martin GB \& Knight TW 1978 Stimulation of the seasonally anovular Merinos ewes by rams. I. Time from introduction of the rams to the pre-ovulatory surge and ovulation. Animal Reproduction Science 1 283-290. (doi:10.1016/0378-4320(79)90013-7)

Rose RM, Gordon TP \& Bernstein IS 1972 Plasma testosterone levels in the male rhesus: influences of sexual and social stimuli. Science $\mathbf{7 8}$ 643-645. (doi:10.1126/science.178.4061.643)

Scaramuzzi RJ \& Baird D 1977 Pulsatile release of LH and the secretion of ovarian steroids in sheep during anestrus. Endocrinology 101 1801-1806. (doi:10.1210/endo-101-6-1801)

Selvaraj N, Israeli D \& Amsterdam A 1996 Partial sequencing of the rat steroidogenic acute regulatory protein message from immortalized granulosa cells: regulation by gonadotropins and isoproterenol. Molecular and Cellular Endocrinology 123 171-177. (doi:10.1016/ S0303-7207(96)03916-0)

Smith MS, Freeman ME \& Neill JD 1975 The control of progesterone secretion during the estrous cycle and early pseudopregnancy in the rat: prolactin, gonadotropin and steroid levels associated with rescue of the corpus luteum of pseudopregnancy. Endocrinology 96 219-226. (doi:10.1210/endo-96-1-219)

Spicer LJ, Chamberlain CS \& Maciel SM 2002 Influence of gonadotropins on insulin- and insulin-like growth factor-I (IGF-I)-induced steroid production by bovine granulosa cells. Domestic Animal Endocrinology 22 237-254. (doi:10.1016/S0739-7240(02)00125-X)

Ungerfeld R 2007 Socio-sexual signalling and gonadal function: opportunities for reproductive management in domestic ruminants. Society of Reproduction and Fertility Supplement 64 207-221.

Received 7 November 2014

First decision 2 January 2015

Revised manuscript received 20 January 2015

Accepted 18 February 2015 